\title{
Globalisation and Poverty: Implications of South Asian Experience for the Wider Debate
}

\section{Jeffery Round and John Whalley*}

\section{Introduction}

Substantial heat and in some ways limited light surrounds the linkages between globalisation and poverty. Despite the allegations and concerns that globalisation adversely affects the poor (Khor 2002; Watkins 2002) and especially so in poorer countries, and counter-claims that it has "supported" poverty reduction (World Bank 2002), conclusive evidence on the linkages and the magnitude of effects is difficult to find. There is extensive literature discussing the possible channels through which globalisation and poverty are linked ${ }^{1}$ and a body of theoretical and empirical literature seeming to provide evidence either in one direction or the other (O'Rourke 2001; McKay et al. 2000; Dollar and Kraay 2001; and Weller and Hersh 2002), so the outcomes are, at best, ambiguous.

Precise definitions of globalisation are elusive, but it is usually perceived as a process of increased integration between and within countries, manifested through an increase in the movement of commodities, labour, capital (financial and physical capital), and technology. The wide-ranging nature of these globalisation processes and the inherent difficulties in identifying and measuring them, in terms of either their initial shocks or their impacts on various parts of the economic system (especially their impact on welfare and poverty) creates a number of analytical and empirical challenges. Even if we focus on just one kind of globalisation shock, trade liberalisation, and consider the consequences analytically (via a modelling framework), the shock might be seen to have quite different effects in different models, under different configurations of otherwise similar models, and based on different experiments (e.g. using different replacement taxes to make tariff reductions revenue neutral).

Equal care is required when clarifying the poverty side of the globalisation and poverty link. It can be interpreted as "money-metric"-based poverty or expressed in terms of more broadly based social indicators (Ravallion 1993). Clearly, the measure of poverty used matters because different poverty indices do not correlate perfectly. Monetary-based measures also vary according to the choice of relative or absolute numbers below poverty lines, on nominal or real incomes, the reference unit (households, individuals, household subgroups); or they may rely on measures of relative poverty based on skilled/unskilled wage differentials, or on the relative incomes of population subgroups. Data on poverty is often fragmentary and where available data may be inconsistent one source compared with another, so inferences are quite difficult to make. ${ }^{2}$

Many of these analytical difficulties have been addressed in an attempt to identify some linkages between globalisation and poverty in four South Asian economies in a project involving researchers from Bangladesh, India, Pakistan and Sri Lanka. ${ }^{3}$ Each researcher executed modelling work aimed at quantitatively evaluating the sign and significance of key elements of linkage; for example, how capital flows and changes in foreign remittances occurring simultaneously with tariff changes influence the results of tariff/inequality studies; how significant export surges in garment industries have been in reducing gender inequality; how the separate influences of trade and technical change occurring under globalisation can be measured; and other such targeted analyses. 
In the course of executing this work, broader questions have also been considered. Just what has been the record on poverty and inequality change in these countries as globalisation processes have occurred? When did major globalisation shocks (such as trade liberalisation) occur and how did inequality measures seemingly respond and when? What does a crude data-based analysis of linkage suggest? What are some of the pitfalls in using data in model-based counterfactual analyses in trying to unearth directions and size of linkage mechanisms? These issues are addressed here by considering some of the broader themes and results that emerge from the project.

In assessing the role of various elements of linkage, a number of points can be made. First, the choice of poverty measure matters. This is not simply a matter of distinguishing between relative and absolute poverty. Outcomes may differ as between measures based on income, consumption, health and education, and other dimensions of human well-being. Second, the structure of models used to unearth linkage is critical. Models with specific immobile factors have localised rents that change in a narrow and prescribed way with trade liberalisation; models with mobile factors do not have this feature. Quotas (if unauctioned) confer rents which liberalisation takes away; quotas which are auctioned or sought (rent-seeking) do not have these features. Third, trade policies that raise revenues (tariffs), if replaced by similar revenue raising instruments (a progressive income tax, or a VAT), may see their perceived inequality effects largely determined by the replacement policies. These are not just abstract, analytical issues, although they can be addressed using models. They reflect differences in economic circumstances that will influence the impact of trade liberalisation on poverty.

Many other pitfalls exist in such analyses, to the point that one can argue that meaningful discussion of the globalisation-poverty linkage can only take place if very precise contours for the discussion exist. Is globalisation inequality-worsening in a particular model of a particular economy using certain assumptions and conducting a precise experiment? Without such specificity, precise answers to the linkage conundrums cannot be given; with any small change in setup the answers could change, often dramatically. On top of this, globalisation is likely to impact on economies in different ways because the appropriate "contours" differ between countries; and because of other factors, such as the influence of institutions and of policy impacts other than those that are directed at liberalisation, which affect the "other things being equal" assumptions modellers are obliged to make.

In taking this perspective, this project differs from the Department of International Development (DFID) handbook on trade liberalisation and poverty (McCulloch et al. 2001) that provided the background framework for the DFID White Paper on globalisation. The authors argued that in general, trade liberalisation is an ally in the fight against poverty' (McCulloch et al. 2001: 3). It did not draw a clear distinction between relative and absolute poverty, although the impacts might be quite different. While it focused on impacts on goods prices, wages and employment, and outlined alternative detailed pathways through which trade liberalisation might have a direct effect on poverty, the study acknowledges that the total effect might be ambiguous, and this accords with our own experience. McCulloch et al. also suggested that agriculture and services were key sectors for poverty alleviation, although they provided limited intersectoral analysis and did not stress the many pitfalls in assessing the nature and magnitude of such a linkage.

The rest of this article is organised into three sections. Section 2 briefly considers the evidence and some of the difficulties (both conceptual and practical) in determining when liberalisation occurs and at what speed, and the apparent changes in poverty during the period of liberalisation. In two of the countries (Sri Lanka and Pakistan) liberalisation was gradual, whereas in India and Bangladesh, liberalisation was much more rapid. Section 3 then draws together some experience from the simulation exercises. There is considerable variety in terms of both the experiments and the modelling approaches. We purposely do not use one single generic model and apply it to each country. Instead, the models range from small, stylised, and more transparent models to much larger, computable general equilibrium (CGE) models embracing macro and micro closures. The final section, Section 4, draws some conclusions about the broad effects of globalisation on poverty from these experiments. 


\section{Assessing the evidence}

\subsection{Dating globalisation shocks in four South Asian economies}

As "globalisation" and "liberalisation" are terms open to such wide interpretation, it is not surprising that there is little consensus about identifying dates when countries may be said to have "globalised" or "liberalised". This issue pervades much of the literature, most notably in the recent paper by Dollar and Kraay (2001), in which they attempt to subdivide a sample of developing countries into "post-1980 globalisers" and the rest (i.e. essentially "nonglobalisers"). Their aim was to consider the relative growth and poverty performance of the two groups. Dollar and Kraay identify post-1980 globalisers in terms of two simple, trade-related measures:

1. An outcome measure, based on the growth in trade relative to GDP.

2. A policy input measure, based on the decline in average tariff rates.

Each measure has some deficiencies and Dollar and Kraay acknowledge certain anomalies in the resulting classifications.

A further measure, the Sachs-Warner index (Sachs and Warner 1997), is more to do with the timing of liberalisation than with the aim of producing a binary classification of countries. Their measure is based on five tests: (1) average tariff rates below 40 per cent; (2) average quota and licensing coverage of imports of less than 20 per cent; (3) a black market exchange premium of less than 20 per cent; (4) no extreme controls (taxes, quota and state monopolies) on exports; and (5) not considered a socialist country by the Kornai standard (Sachs and Warner 1997: 339). An economy is deemed to be open to trade if all five tests are satisfied. In principle of course, the Sachs-Warner index could be used to identify the speed as well as the timing of liberalisation, by observing how rapidly the five tests are satisfied. However, each test is scored on a pass/fail basis, so it would give no indication of how rapidly average tariff rates or average quota coverage are reduced. It would only indicate the rate at which the cumulative position on the five tests has been attained.

Some countries are generally believed to have liberalised more quickly than others in terms of key indicators (especially trade and financial indicators). Nevertheless, these different indicators of liberalisation give differing results. The four South Asian countries considered here are a case in point. India and Bangladesh satisfy both of Dollar and Kraay's criteria as "post-1980 globalisers" and are included in their list. Pakistan passes the second criterion (tariff reduction), but not the first (Dollar and Kraay seem unconvinced by its inclusion anyway), and Sri Lanka does not appear at all in their classifications. However, in the original Sachs-Warner index (Sachs and Warner 1997), the picture is a little different. Sri Lanka and India are included in the list of developing countries that had "opened" by 1994 (after initial closure) and Bangladesh and Pakistan are in the list of countries that were still closed by 1994. But all four countries have now liberalised, at least to a large degree. What really distinguishes them is the speed at which they have liberalised.

A detailed examination of the evidence in relation to trade, based on changes in tariff rates and quota coverage (input measures) and openness ratios (outcome measures), suggests the following. Pakistan has been relatively slow in liberalising trade, commencing late 1980s and through the 1990s. In contrast, a series of liberal policy reforms, involving both trade and financial liberalisation and privatisation, were introduced in Bangladesh in 1990, leading to significant reductions in tariff and quota reductions during the following decade, although in terms of other facets of liberalisation (e.g. financial direct investment, and financial integration) the reform process has been much slower.

In India, through the 1990s, tariff levels were reduced quite significantly and quotas also experienced some relaxation. But economic reform in India involved more than trade liberalisation. The devaluation in 1991 was also significant, as were the relaxation of exchange controls previously applying to both capital and current accounts, and restrictions on FDI inflows. In contrast, Sri Lanka embarked on a series of trade reform measures much earlier - in 1977, when exchange control was dismantled, tariffs were reduced and quota restrictions began to be removed. The main feature of Sri Lanka's liberalisation is not so much the degree and intensity of reform, but the relatively long time over which the reforms were introduced. 


\subsection{Identifying poverty responses in an era of globalisation}

The broad picture on the changes in absolute and relative poverty experienced during the last two decades in each of the four South Asian countries under study can be set against the background of their records on globalisation. As discussed above (Section 1) it is often quite difficult to provide a clear and unequivocal assessment of either levels or changes in poverty. Even when a money-based measure of poverty is used, many alternative poverty measures exist to measure and assess changes in poverty. So a first aim is to provide some broad overall indications of the magnitude and directions of change, distilled from the individual project material. In most cases the evidence accumulated is predominantly based on the contributing researchers' own poverty assessments carried out under the MIMAP project (see note 3).

In broad terms, evidence on poverty in the South Asian countries suggests that a major change has occurred in terms of absolute poverty (expressed as a headcount index, that is, the numbers below the poverty line) and that this change has accelerated as growth performance has picked up postliberalisation. However, the results are far from unidirectional. It is now generally agreed, in the light of some mixed evidence, that absolute poverty has declined in India during the 1990s and a similar picture has emerged in Bangladesh. This underlines the broad evidence for South Asia as a region. In Pakistan, however, following a decline in poverty in the early 1990s, there has been some volatility in the poverty ratios, though set against a rising trend. In Sri Lanka, after some apparent increase in absolute poverty during the early 1980s and a decline in the second half of the 1980s, there was a further increase in the 1990s.

With regard to relative poverty (inequality) in the region over the last few decades, the broad picture is that it has remained relatively unchanged (at least until recently) in spite of major trade liberalisation in the late 1980s and early 1990s. Still, from the evidence available, there are some differences between countries; increasing inequality in Pakistan post-liberalisation; a period of slightly increasing and then falling inequality in Bangladesh post-liberalisation; a similar increase then fall in inequality in Sri Lanka, though this occurs over a much longer horizon; and some evidence of sharper increases in inequality in India in the late 1990s.
However, it is difficult to ascribe precise reasons for these different outcomes.

\section{Evaluating the mechanisms of globalisation/poverty linkage in South Asia}

Against this mixed and uncertain picture of dating globalisation shocks and assessing changes in absolute and relative poverty, the next step is to assess what form the linkages actually take. Globalisation shocks in South Asia appear worthy of careful study because, to the outside observer, they appear to have occurred dramatically and to be concentrated over a relatively short time period. The view might be that if there are discernible impacts of globalisation on poverty, then surely they could show through in these cases. However, the central difficulty is that the statistical outcome observed reflects the combined influence of several factors, some of which are seemingly unconnected with liberalisation per se. For example, work on poverty reduction in Vietnam (Niimi et al. 2003) in the period following liberalisation suggests that trade liberalisation accounts for a small share of overall poverty reduction, with changes in domestic policy being more important. Therefore, some form of counterfactual analysis is therefore needed to isolate the component of the overall change that is attributed to globalisation influences. Considering trade liberalisation, primarily in the South Asian countries but also in OECD export markets, a number of channels of influence on poverty and inequality can be identified.

\subsection{Tariff-based liberalisation}

The central form of linkage to poverty from tariffbased liberalisation discussed in the theoretical literature is from relative goods prices that change as tariffs fall relative to factor prices. These effects are associated with Stolper and Samuelson (1941) who provided conditions under which the factor that is intensive in the production of importables would lose out. Stolper-Samuelson effects in the South Asian case would therefore appear as a reduction in the relative return to labour used in protected sectors, typically being more skilled labour. These effects are widely thought to be propoor.

Many other factors influence the way trade liberalisation impacts on poverty. If the rich purchase relatively more of the imported good, then reductions 
in tariffs will be more beneficial to them on the demand side. If there are fixed, or specific, factors used in production, then the owners of these factors rather than owners of factors more generally, will be the losers. Depending upon how tariff revenues are, or are not, replaced, various distributional effects will follow. Replacing revenues using a progressive income tax will have different effects from a VAT or payroll tax, for instance. If tariffs are reduced while quotas remain in place, the effects of the tariff reductions are only lump sum since they merely increase the value of the quota rents. Other distortions in the economy may be germane too. For example, if labour in the traditional (agricultural) sector is paid its average product, and the price of labour in the modern sector is determined by its marginal product, then tariffs can affect these distortions and intersectoral migration patterns may well be affected by the policy change.

\subsection{Quota-based liberalisation}

The South Asian economies were characterised, pre-liberalisation, by extensive use of quotas and other trade restraints, as well as tariffs. However, quotas, when changed, might produce quite different effects on poverty compared with tariffs. A number of sub-cases can be identified. One case is where import quotas are merely allocated by national governments, so recipients of quotas also receive quota rents. In this case, trade liberalisation that removes the quotas also takes away the quota rents. If quotas are allocated to the rich, such liberalisation becomes pro-poor in its income redistribution effects, in addition to having the relative goods and factor prices effects that were noted above for the tariff case. A second case is where the quotas are auctioned by governments; in this case, revenues accrue very much as in the tariff case. In these situations, the poverty implications of tariff- and quota-based liberalisation become very similar.

A third case is where quotas are sought after via rent-seeking behaviour that uses real resources. Examples would be taking on surplus labour to demonstrate unemployment in the enterprise so that a licensing board will allocate quotas for imports of machinery. Such instances are discussed for India pre-liberalisation in Mohammed and Whalley (1984) who, for India in the 1970s, estimated rent-seeking costs for all major policy interventions in India (i.e. not just trade) at 15-40 per cent of GDP. If rent- seeking accompanies trade-based quotas, then, on the removal of these quotas, real resources are saved, potentially leading to positive income effects.

\subsection{Economy-wide models}

The ways in which these elements of linkage can be investigated usually involve the use of numerical simulation models, typically of the general equilibrium variety. Econometric methods are unable to deal with the richness and detail of the underlying structural forms involved and generally are not used. Parameter estimates based on past behaviour or existing structure may not give adequate clues as to what might be the case after the policy "shock". Therefore, numerical simulation and computable general equilibrium modelling approaches are much more useful for counterfactual analysis - that is, to examine the likely (or possible) consequences from some change in the initial situation. This implies that most analyses are ex ante: they are attempts to examine "what" might be the economy-wide responses "if" some exogenous change (a policy change) were to take place.

The typical procedure is to build a model with goods and factors, with trade in goods but no trade in factors. Such models are usually calibrated to a base year data set around which counterfactual equilibrium analysis is performed (see Shoven and Whalley 1992). The counterfactuals typically involve the removal or reduction of tariffs and quotas, with an equal yield replacement tax in the tariff case (often a VAT surcharge).

Increasingly, these models are being used in double calibration mode with calibration taking place to two separate years of data. In this case the models are being used ex post rather than ex ante; the aim being to see how important one or other of a number of components of a combined change are for a change that has already occurred (such as a change in inequality). The methods used for this are discussed in Abrego and Whalley (2002).

Many issues arise with using these numerical simulation models. One is that the precise structural form used can, to a large degree, predetermine the conclusions. First, models with fixed factors, that is for instance, where labour and/or capital cannot move freely between sectors, tend to yield concentrated outcomes from liberalisation, while models with mobile factors yield smaller but broader economy-wide effects. So in reality, the degree of mobility of factors is important to the effects of 
Table 1: Recent numerical models evaluating linkage between trade liberalisation and poverty

\begin{tabular}{|c|c|c|c|c|}
\hline Author & Country & Type of model & $\begin{array}{l}\text { Base year data } \\
\text { used in calibration }\end{array}$ & Conclusion \\
\hline $\begin{array}{l}\text { Weerahewa } \\
\text { (2002a) }\end{array}$ & $\begin{array}{l}\text { Sri Lanka } \\
\text { Ricardo-Viner } \\
\text { type model }\end{array}$ & Static 2 sector & $\begin{array}{l}\text { Double calibration } \\
\text { to pairs of years } \\
(1977,1994,2000)\end{array}$ & $\begin{array}{l}\text { Trade plays no essential role in } \\
\text { explaining poverty change } \\
\text { (either relative or absolute). } \\
\text { Technical change and endowment } \\
\text { changes are the main drivers }\end{array}$ \\
\hline $\begin{array}{l}\text { Mujeri and } \\
\text { Khondker } \\
\text { (2002b) }\end{array}$ & Bangladesh & $\begin{array}{l}\text { Static } 2 \text { sector } \\
\text { Ricardo-Viner } \\
\text { type model }\end{array}$ & $\begin{array}{l}\text { Double calibration } \\
\text { to } 1985 \text { and } 1996 \\
\text { data }\end{array}$ & $\begin{array}{l}\text { Trade is the minor determinant } \\
\text { of poverty change compared with } \\
\text { technical change and endowment } \\
\text { growth }\end{array}$ \\
\hline $\begin{array}{l}\text { Siddiqui and } \\
\text { Kemal } \\
(2002 a)\end{array}$ & Pakistan & $\begin{array}{l}\text { Static } 11 \text { sector } \\
\text { Ricardo-Viner } \\
\text { type model }\end{array}$ & $\begin{array}{l}\text { Single calibration } \\
\text { to data for 1989-90 } \\
\text { and forward } \\
\text { projections }\end{array}$ & $\begin{array}{l}\text { Non-globalisation variables are key } \\
\text { to understanding how globalisation } \\
\text { affects poverty measures. Model } \\
\text { runs including or excluding } \\
\text { remittance changes alter the sign } \\
\text { of effects }\end{array}$ \\
\hline $\begin{array}{l}\text { Pradhan } \\
\text { (2002b) }\end{array}$ & India & $\begin{array}{l}\text { Static } 13 \text { sector } \\
\text { Ricardo-Viner } \\
\text { type model }\end{array}$ & $\begin{array}{l}\text { Single calibration } \\
\text { to data for } 1994 \\
\text { and forward } \\
\text { projections }\end{array}$ & $\begin{array}{l}\text { Trade policy change has small } \\
\text { impact on poverty effects }\end{array}$ \\
\hline $\begin{array}{l}\text { Chan and } \\
\text { Dung (2001) }\end{array}$ & Vietnam & $\begin{array}{l}\text { Static 12-sector } \\
\text { fixed factor } \\
\text { model }\end{array}$ & $\begin{array}{l}\text { Single calibration } \\
\text { to data for } 1997 \\
\text { and forward } \\
\text { projection }\end{array}$ & $\begin{array}{l}\text { Trade policy change is pro-rich, } \\
\text { since in Vietnam consumption } \\
\text { data suggest the rich buy } \\
\text { proportionately more imports than } \\
\text { the poor }\end{array}$ \\
\hline
\end{tabular}

liberalisation. This has implications for policy, in that labour market policies that promote migration, micro-credit, etc. and which more generally increase the mobility of labour and capital, may spread the effects of liberalisation more widely. Second, shortrun models with adjustment costs can produce sharply different implications from those of longer run models without them (see Edwards and Whalley 2002). Third, results are highly parameter dependent. Typically, a subset of key model parameters is pre-selected (such as key elasticities of substitution) and it can be observed that liberalisation impacts change as parameter values change, often quite sharply. General results are thus typically not generated by numerical simulation; the results are therefore indicative rather than definitive and it is orders of magnitude and directions of effect, rather than precise numerical outcomes that are achieved from the analyses.

Yet another issue is how poverty is analysed using these approaches. Some models tend to analyse factor price effects (such as the differential between skilled and unskilled wage rates), rather than a broader concept of income including capital income and transfers and taxes. Siddiqui and Kemal's (2002a) data for Pakistan suggests a high income share for capital income (perhaps 30 per cent in aggregate) indicating how partial this approach is. Others are large models based on social accounting matrices. Some modelling efforts (such as Cockburn 2001) have attempted to add microsimulation detail to conventional factor incometype analyses. These approaches allow for calculations of movement of individual incomes 
above and below the poverty line, and other broader measures of income change, but rely heavily on ad hoc assumptions and assumed parameter values.

\subsection{Results from the models}

In Table 1, we have attempted to summarise some of the results from a sample of numerical simulation models used to analyse globalisation/poverty linkages, mainly in the South Asian countries, but with Vietnam added due to its policy relevance.

Three of the papers (Weerahewa 2002a; Mujeri and Khondker 2002b; and Pradhan 2002a) use double-calibration techniques for simple models of Sri Lanka, Bangladesh and India respectively to analyse the relative importance of trade, technical change, and endowment change as determinants of inequality change. They take liberalisation to be given by the actual tariff and quota changes for the years that are analysed, looking at revenuepreserving change.

A feature of these models is that they all embody some degree of factor specificity. This is due to a general model feature that if models capture all factors as being fully mobile across sectors then typically only a relatively small range of factor price changes can be accommodated as resulting from a goods price change without encountering problems of equalisation. These problems are also noted in Johnson (1966) and Abrego and Whalley (2002) and are widely accepted in the modelling literature. As a result, pure Stolper-Samuelson effects do not show through from these models because rewards to fixed factors are involved. Nonetheless, these studies all point to the conclusion that the influences of trade-based liberalisation, and of trade in general, on both absolute and relative poverty (i.e. inequality) are quite small. This is the strong and broad conclusion from these studies.

Other results shed further light on this conclusion. Siddiqui and Kemal (2002a) show how, in the Pakistan case, there is a clear and potentially major role for excluded variables in the analysis of linkage. As noted earlier, in the early 1990s both absolute and relative poverty increased in Pakistan. But this occurred along with a reduction in remittances that previously went primarily to the poor (as a percentage of income). Thus if the remittance change is removed from the analysis then trade changes alone generate an opposite effect in terms of both absolute and relative poverty.

Table 1 also refers to results from a Vietnam model project, which, while not part of the South Asia project, is also germane to the cases here. These results show trade policy changes to be pro-rich based on household budget data that show expenditure shares on imports to be significantly higher for the rich than for the poor. Other studies, not cited in Table 1, shed further light on these linkages. Pradhan (2002a) analysed both tariffbased and quota-based liberalisation in India, showing how impacts on inequality measures under liberalisation change. Mujeri and Khondker (2002a) carried out a similar study for Bangladesh analysing effects on poverty measures. Siddiqui and Kemal (2002b) analyse the poverty impacts of trade liberalisation under scenarios where capital flows are also liberalised at the same time, concluding that relatively little added impact occurs. Weerahewa (2002b) analyses how outward trade surges in textiles and apparel from Sri Lanka impact on the relative male-female ratio, concluding that outward orientation has served to partially lower the gap in this case. Bussolo and Whalley (2002) show how in the Indian case, reductions in transaction costs ${ }^{4}$ that occur contemporaneously with trade liberalisation also serve to impact on relative wage inequality, and may help to explain a reduction in the relative wage gap between skilled and unskilled labour in the early period of liberalisation in India.

\section{Conclusions}

To assess the effects of globalisation shocks in South Asia, we have examined the four cases of Pakistan, Sri Lanka, India and Bangladesh during the 1980s and 1990s. At first sight, they seem to be cases of declining absolute poverty, which accelerates some time after liberalisation and relatively constant inequality. There are departures from this situation, rising absolute and relative poverty in Pakistan, and a few years of increasing relative poverty in Bangladesh. All in all, at a broad sweep of the brush the picture seems to be one of almost no impact on relative poverty (i.e. inequality) and some acceleration (through higher growth) in the decline of absolute poverty. However, separating out the linkages from other effects and influences, many problems are encountered. There are conceptual problems with measuring and dating liberalisation. These are measurement and data problems in ascertaining exactly what has happened to poverty changes over the time period, especially with regard to different measures and income concepts. There 
are problems with model-based analyses. Model structures make a difference, as does the precise liberalisation experiment used. Hence, even in a case where, at first sight, the linkages between globalisation and poverty are seemingly exposable, conceptual, data, and modelling issues preclude overly firm conclusions. Specificity of experiment, of the model, and other factors all matter greatly.

The general and overriding conclusion from these analyses is that the debate on globalisation and poverty linkages appears to be pitched at too general

\section{Notes}

* This article is a revised version of an overview paper of the project 'Exploring the Links Between Globalisation and Poverty in South Asia', which is part of the Globalisation and Poverty Programme, funded by the UK Department for International Development (DFID). We wish to thank John Humphrey, the Programme Director, for valuable comments on an earlier draft and for his support to the project as a whole. Statistical details have been excluded, although these may be obtained from the earlier version, Round and Whalley (2002).

1. For example, McCulloch et al. (2001) review the transmission channels of trade liberalisation on poverty.

2. Throughout this article, inequality is referred to as 'relative poverty' in order to reflect the income or well-being of one group (e.g. the poor) relative to another (e.g. the rich).

\section{References}

Abrego, L. and Whalley J., 2002, 'Decomposing wage inequality change using general equilibrium models', NBER Working Papers 9184 , Washington, DC: National Bureau of Economic Research

Bussolo, M. and Whalley, J., 2002, 'Globalisation in developing countries: the role of transaction costs in explaining economic performance in India', DFID Project Paper, www.oecd.org/ dataoecd/59/22/2503649.pdf (accessed 9 October 2003)

Chan, N. and Dung, T.K., 2001, Development of a CGE Model to Evaluate Tariff Policy in Vietnam, MIMAP Modelling Meeting, Singapore, www.bellanet.org/mimap/dynamic/dyn_workin pr2/vnpaper2-10.doc?OutsideInServer=rules (accessed 7 October 2003)

Cockburn, J., 2001, Trade Liberalisation and Poverty in Nepal, A Computable General Equilibrium Micro Simulation Analysis, Canada: CREFA, Université a level - even in these country cases - to be able to draw firm conclusions. There is no firm theoretical link between globalisation and poverty; the empirical evidence is difficult to disentangle, not least because so many events occur contemporaneously. Numerical simulation methods and models are useful in separating effects but usually under strict "other things being equal" conditions of one form or another. Thus, policy conclusions are necessarily severely constrained by circumstances and are heavily conditioned as a result.

3. The researchers are: Jeevika Weerahewa (Sri Lanka), Rizwana Siddiqui and A.R. Kemal (Pakistan), Bazlul Khondker and Mustafa Mujeri (Bangladesh) and Basanta Pradhan (India). The project was also co-linked to the Micro Impacts of Macroeconomic and Adjustment Policies (MIMAP) network of researchers on poverty analysis and modelling in these and other countries in Asia and Africa. This network is funded by the International Development Research Centre (IDRC).

4. Transaction costs in this context refer to several forms of impediments to transactions between buyers and sellers. These include the costs of transportation, communication and information transfer and include policy-induced restrictions and controls.

Laval Québec, www.crefa.ecn.ulaval.ca/cahier/ 0118.pdf (accessed 7 October 2003)

Dollar, D. and Kraay, A., 2001, 'Trade, growth and poverty', paper presented to the WIDER conference on 'Growth and Poverty', May, www.wider.unu.edu/conference/conference2001-1/dollar\%20and\%20kraay.pdf (accessed 7 October 2003)

Edwards, T.H. and Whalley, J., 2002, 'Short and long run decompositions of OECD wage inequality changes', NBER Working Papers 9265, Washington, DC: National Bureau of Economic Research

Johnson, H.G., 1966, 'Factor market distortions and the shape of the transformation curve', Econometrica, Vol 34: 686-698

Khor, M., 2002, 'A perspective of globalisation and its implications for developing countries', paper presented to the CSGR conference on Globalisation, Growth and (In)Equality, University of Warwick, March, www.warwick.ac.uk/fac/ soc/CSGR/PKhor.pdf (accessed 7 October 2003) 
McCulloch, N., Winters, L.A. and Cirera, X., 2001, Trade Liberalisation and Poverty: A Handbook, London: Centre for Economic Policy Research

McKay, A., Winters L.A. and Kedir, A.M., 2000, 'A review of the empirical evidence on trade, trade policy and poverty', Report to DFID prepared as a background document for the Second Development White Paper, www.globalisation. gov.uk/BackgroundWord/EmpiricalEvidenceOnTr adeAndrewMcKay.doc (accessed 7 October 2003)

Mohammed, S. and Whalley, J., 1984, 'Rent-seeking in India: its costs and policy significance', Kyklos, Vol 37 No 3: 387-413

Mujeri, M. and Khondker, B., 2002a, 'Poverty implications of trade liberalisation in Bangladesh: a general equilibrium approach', DFID Project Paper, www.gapresearch.org/production/Mustafa Pov.pdf (accessed 9 October 2003)

Mujeri, M. and Khondker, B., 2002b, 'Decomposing wage inequality change in Bangladesh: an application of the double calibration technique', DFID Project Paper, www.gapresearch.org/ production/MusafaDecomp.pdf (accessed 9 October 2003)

Niimi, Y., Vasudeva-Dutta, P. and Winters, L.A., 2003, 'Trade liberalisation and poverty dynamics in Vietnam', PRU Working Paper 17, Brighton: Poverty Research Unit, University of Sussex

O’Rourke, K., 2001, 'Globalisation and inequality: historical trends', CEPR Discussion Paper 2865, London: Centre for Economic Policy Research

Pradhan, B., 2002a, 'The role of education in wage inequality change in India: 1988-97', DFID Project Paper

Pradhan, B., 2002b, 'Debating the effects of trade liberalisation on poverty: how experiment specificity determines the conclusions', DFID Project Paper, www.gapresearch.org/production/ BasantaPov.pdf (accessed 9 October 2003)

Ravallion, M., 1993, 'Poverty comparisons', Fundamentals of Pure and Applied Economics, Vol 56, Chur, Switzerland: Harwood Academic Press Round, J.I., and Whalley, J., 2002, 'Globalisation and poverty: implications of South Asian experience for the wider debate', DFID Project Paper,
www.gapresearch.org/production/JJoverview .pdf (accessed 7 October 2003)

Sachs, J.D. and Warner, A.M., 1997, 'Sources of slow growth in African economies', Journal of African Economies, Vol 6 No 3: 335-376

Shoven, J. and Whalley, J., 1992, Applying General Equilibrium, Cambridge: Cambridge University Press

Siddiqui, R. and Kemal, A.R., 2002a, 'Remittances, trade liberalisation and poverty in Pakistan: the role of excluded variables in poverty change analysis', DFID Project Paper, www.gapresearch.org/ production/RizwanaRemittR2.pdf (accessed 9 October 2003)

Siddiqui, R. and Kemal, A.R., 2002b, 'Poverty inducing or poverty reducing? A CGE-based analysis of foreign capital inflows in Pakistan', DFID Project Paper, www.gapresearch.org/ production/RizwanaFKI2.pdf (accessed 9 October 2003)

Stolper, W.F. and Samuelson, P.A., 1941, 'Protection and real wages', Review of Economic Studies, Vol 9: $58-73$

Watkins, K., 2002, 'Making globalisation work for the poor', Finance and Development, Vol 39 No 1, 24-26 March (and a response by Dollar and Kraay, 27-28)

Weerahewa, J., 2002a, 'Assessing the impacts of globalisation on poverty using decomposition methods', DFID Project Paper, www.gapresearch.org/ production/JeevikaPov.pdf (accessed 9 October 2003)

Weerahewa, J., 2002b, 'Globalisation and malefemale inequality in Sri Lanka: short-run and long-run impacts', DFID Project Paper, www.gapresearch.org/production/JeevikaTex.pdf (accessed 9 October 2003)

Weller, C. and Hersh, A., 2002, 'The long and short of it: global liberalisation, poverty and inequality', Washington, DC: Economic Policy Institute, www.zei.de/download/zei_wp/B02-14.pdf (accessed 7 October 2003)

World Bank, 2002, Globalisation, Growth and Poverty: Building an Inclusive World Economy, New York: Oxford University Press for the World Bank 